\title{
Effects of Sewage Sludge Ashes Addition in Portland Cement Concretes
}

\author{
Fernandes de Lima, Jeffersson \\ Escola de Ciências e Tecnologia \\ Universidade Federal do Rio Grande do Norte, Campus \\ Universitário \\ Natal/RN, 59072-970, Brazil.
}

\author{
Durante Ingunza, Maria del Pilar \\ Civil Engineering Department, Centro de Tecnologia, \\ Universidade Federal do Rio Grande do Norte, Campus \\ Universitário, \\ Natal/RN, 59072-970, Brazil.
}

\begin{abstract}
Due to worldwide awareness of the need for environmental preservation, considerable weight has been given to developing technologies and methods that promote sustainability, underscoring studies on recycling urban solid waste such as sewage sludge ash (SSA) as a source of raw materials for this industry. Following this tendency, the present study aimed at assessing the technical implications of using SSA as an addition in the preparation of Portland cement concrete on the workability, axial compressive strength, void ratio and water absorption properties of samples produced with $0 \%, 5 \%, 10 \%$ and $15 \%$ of waste in relation to mass of sand used. The results of this study showed that up to $10 \%$ of SSA could be added to the concrete mixtures without compromising axial compressive strength, void ratio and water absorption. Moreover, it was found that using this waste induced a loss of workability in the concretes produced.
\end{abstract}

Keywords- sewage sludge ash; concrete; solid waste.

\section{INTRODUCTION}

With the growth and development of the world's population, the consumption of natural resources and energy has increased, as has the production of waste, primarily in large urban centres, causing considerable concern regarding environmental preservation. This concern has been emphasized in studies aimed at recycling wastes produced by civil construction, a major consumer of natural raw materials worldwide.

Sewage sludge is among the main urban wastes because of the large volume produced, difficult treatment and final disposal. Incineration of this waste has emerged as an alternative for reducing its original volume, and according to Donatello and Cheeseman [1], produces around 17 million tons of SSA per year. Although it does not contain pathogenic organisms or toxic organic compounds, it still poses a contamination risk to the environment, given that the existence of ash as a byproduct of incineration, albeit in a smaller volume, requires that it be disposed of.

Different ways of using SSA as construction material are suggested [2-10] as alternatives for the beneficial recycling of raw material.

In this respect, the present study assesses the technical implications of adding different amounts of SSA to the mass of sand used in preparing concrete, analyzing its effects on the properties of concrete in the fresh and hardened state, using workability, axial compressive strength, void ratio and water absorption tests.

\section{EXPERIMENTAL PROCEDURES}

\section{A. Materials}

The SSA used in this study was obtained by burning septic tank sludge at a temperature of $850{ }^{\circ} \mathrm{C}$ for $12 \mathrm{~h}$, followed by slow cooling in the same oven until the ambient temperature of $30{ }^{\circ} \mathrm{C}$ was reached. Scanning Electron Microscopy (SEM) indicated that this waste, whose chemical composition was determined by XRF analyses (Table 1), exhibited irregular grain morphology and considerably rough surface (Fig. 1) This material had a specific mass of $2,68 \mathrm{~g} / \mathrm{cm}^{3}$, as determined by Brazilian standard [11], a value similar to that obtained by other authors [7].

TABLE 1. CHEMICAL COMPOSITION OF SSA

\begin{tabular}{|c|c|c|c|c|c|c|c|c|c|}
\hline Oxides & $\mathrm{SiO}_{2}$ & $\mathrm{Al}_{2} \mathrm{O}_{3}$ & $\mathrm{SO}_{3}$ & $\mathrm{CaO}$ & $\mathrm{Fe}_{2} \mathrm{O}_{3}$ & $\mathrm{P}_{2} \mathrm{O}_{5}$ & $\mathrm{MgO}$ & $\mathrm{TiO}_{2}$ & $\mathrm{~K}_{2} \mathrm{O}$ \\
\hline$(\%)$ & 35,14 & 27,65 & 5,30 & 6,16 & 5,60 & 5,52 & 3,72 & 1,22 & 0,76 \\
\hline Oxides & $\mathrm{ZnO}$ & $\mathrm{CuO}$ & $\mathrm{MnO}$ & $\mathrm{ZrO}_{2}$ & $\mathrm{Cr}_{2} \mathrm{O}_{3}$ & $\mathrm{PbO}$ & $\mathrm{SrO}$ & $\mathrm{NiO}$ & LOI* \\
\hline$(\%)$ & 0,35 & 0,10 & 0,05 & 0,03 & 0,03 & 0,01 & 0,01 & 0,01 & 8,37 \\
\hline
\end{tabular}

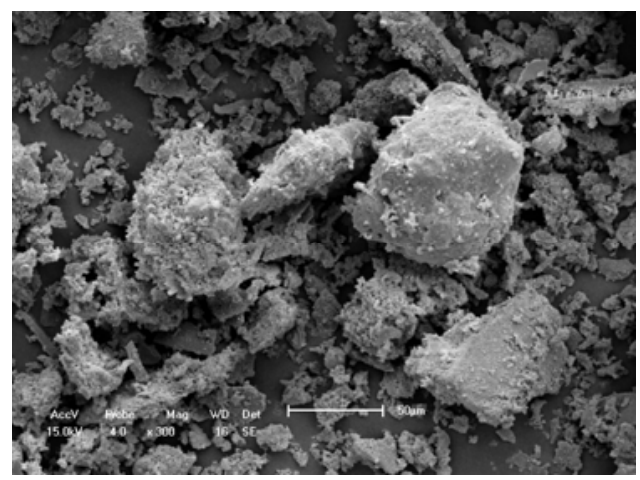

Fig. 1. Grain morphology of SSA

Quartz sand and granite gravel with specific masses of $2,61 \mathrm{~g} / \mathrm{cm}^{3}$ e $2,70 \mathrm{~g} / \mathrm{cm}^{3}$, respectively, as determined by Brazilian standard NBR NM 52 [12], were used as natural aggregates. Granulometric distribution of these aggregates and the SSA (Fig. 2) were determined according to Brazilian standard NBR NM 248 [13]. Portland pozzolan 
cement (32 Mpa), which is resistant to sulfates and an alkali-aggregate reactivity inhibitor, was selected because it is widely produced in Brazil and readily available in the local market. The physical traits of this cement were in accordance with values recommended by Brazilian standard NBR 5736 [14], as shown in Table 2.

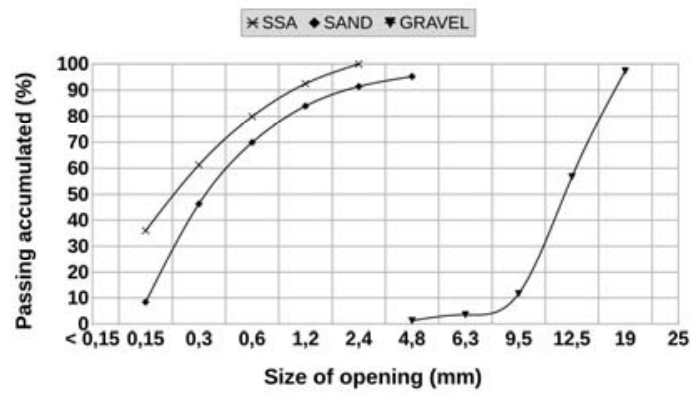

Fig. 2. Grain size distribution of aggregates and SSA

TABLE. 2. PHYSICAL CHARACTERISTICS OF CEMENT

\begin{tabular}{l|c|c}
\hline & $\begin{array}{c}\text { Requirement } \\
\text { specified* }\end{array}$ & Obtained \\
\hline Fineness (\%) & $\leq 8$ & 0,34 \\
\hline Blaine fineness $\left(\mathrm{cm}^{2} / \mathrm{g}\right)$ & Not specified & 5458,00 \\
\hline Initial setting time (min) & $\geq 60$ & 178,40 \\
\hline Final setting time (min) & $\leq 600$ & 253,60 \\
\hline Soundness by Le Chatelier test (mm) & $\leq 5$ & 0,00 \\
\hline Compressive strength - 3 days (MPa) & $\geq 10$ & 20,49 \\
Compressive strength - 7 days (MPa) & $\geq 20$ & 28,18 \\
\hline Compressive strength - 28 days (MPa) & $\geq 32$ and $\leq 49$ & 39,94 \\
\hline
\end{tabular}

* by Brazilian standard NBR 5736 (ABNT 1999)

\section{B. Specimens}

The control mixture consisted of a concrete mass ratio of 1:2:3 (cement: sand: gravel), containing $0 \%$ SSA in its composition and a water/cement ratio of 0.65 . This composition was used because it is an economically feasible formulation that facilitates the addition of the waste under study without the need for plastifying additives in the other proposed mixtures. The control mixture produced three additional mixtures containing $5 \%$, $10 \%$ and $15 \%$ in relation to the mass of sand used (Table $3)$.

TABLE 3. PROPORTION OF THE CONCRETE MATERIALS

\begin{tabular}{c|c|c|c|c|c}
\hline Concrete & Cement & Sand & Gravel & Water & SSA \\
\hline Control & 1,00 & 2,00 & 3,00 & 0,65 & 0,00 \\
\hline Type 01 & 1,00 & 2,00 & 3,00 & 0,65 & 0,10 \\
\hline Type 02 & 1,00 & 2,00 & 3,00 & 0,65 & 0,20 \\
\hline Type 03 & 1,00 & 2,00 & 3,00 & 0,65 & 0,30 \\
\hline
\end{tabular}

Ash was used to complement the sand because its granulometry and specific mass are similar to that of the natural aggregate used in the mixtures.

Immediately after production of the concretes proposed in Table 3, they underwent slump tests, in accordance with Brazilian standard NBR NM 67 [15], followed by the casting of $9100 \times 8200 \mathrm{~mm}$ (diameter $\mathrm{x}$ height) cylindrical concrete samples for each mixture, with a slump of more than $0 \mathrm{~mm}$ and subsequent damp curing according to Brazilian standard NBR 5738[16]. For each type of concrete, 3 of the cylindrical cast samples were used in the void ratio and water absorption tests at 28 days and 6 in uniaxial compressive strength tests at 7 and 28 days, conducted in accordance with Brazilian standards $[17,18]$.

\section{RESUltS AND DISCUSSION}

\section{A. Concrete workability}

As observed in experiments performed by Monzó et al. (2003) e Cyr et al. ( 2007), who observed a decline in mortar workability with an increase in SSA in their mixtures, the results of the present study also showed that a rise in SSA significantly reduced concrete workability, causing zero slump in the sample containing $15 \%$ addition (Fig. 3).

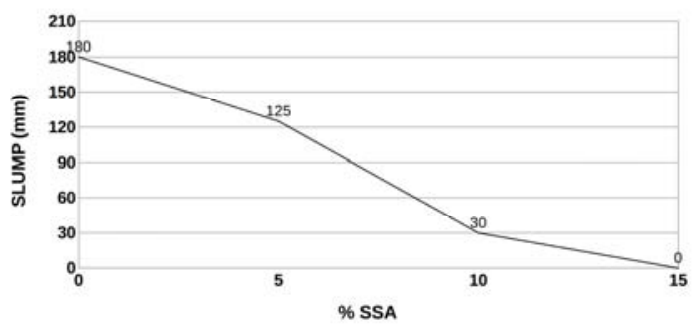

Fig. 3. Workability of concrete produced

This tendency to slump reduction in concrete as a function of the increase in SSA content is provoked by both the decrease in water/dry matter ratio in the mixtures and the hygroscopic nature of the SSA, owing to its granulometric characteristics and grain morphology, which allowed this waste to act in cement matrices as structures that absorb the free water in the mixture.

\section{B. Axial compressive strength}

The addition of ash resulted in a significant improvement in the cohesion of these structures, in addition to reducing exsudation in these samples. These factors contributed to the findings exhibited in Fig. 4, where addition of the waste under study provides greater strength to concretes compared to that of concrete with no waste at both control times tested. 


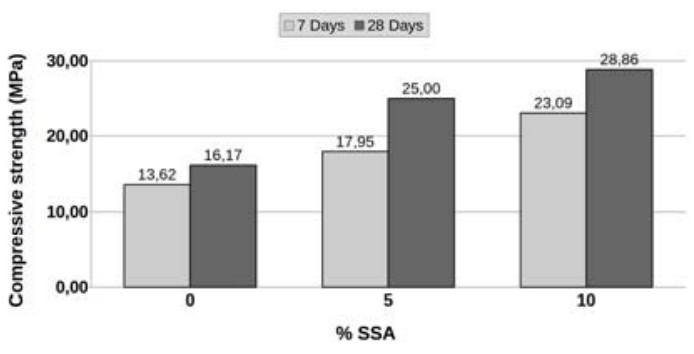

Fig. 4. Compressive strength of concrete produced

\section{Void index and absorption water}

Taking the concrete with $0 \%$ SSA as reference, the results obtained for these tests (Fig. 5) demonstrate that the addition of SSA to concretes provokes a slight decrease in both void ratio and water absorption in the samples analyzed. This behavior is attributed to the refinement of pore structure in these concretes, due to the thin fraction $(<150 \mu \mathrm{m})$ of grains present in the waste under study.

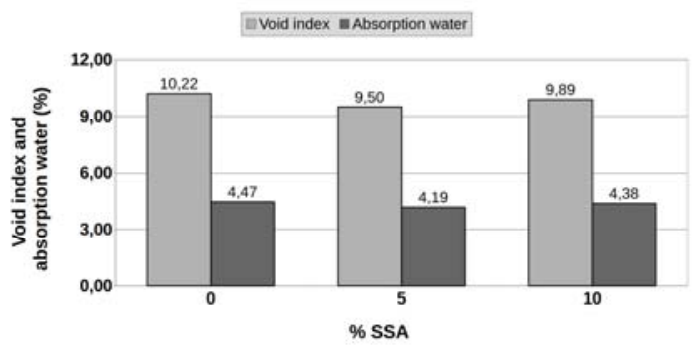

Fig. 5. Void index and absorption water of concrete produced

\section{CONCLUSIONS}

Although SSA caused a significant loss in workability in fresh concrete during the castings, this waste was considerably beneficial in retaining the existing free water, as well as increasing the cohesion of mixtures containing $5 \%$ and $10 \%$ of these ashes. These improvements in fresh concrete have a direct effect on the mechanical properties of samples in the hardened state, where SSA produced significant gains in compressive strength in concretes containing this waste. Moreover, the addition of ash to the mixtures led to an improvement in both void ratio and water absorption in the samples analyzed. However, at very low levels, the use of SSA in the concretes, in the manner and percentages applied in the present study, did not significantly change these properties. This study concluded that the maximum addition of SSA to concrete manufactured without plastifying additives is $10 \%$ in relation to the mass of sand used in concrete composition. This is because higher concentrations require an increase in the water/agglomerate ratio in the mixture, a condition that may result in increased porosity and consequent reduction in the mechanical strength of these cement matrices.

\section{REFERENCES}

[1] Donatello, S. and Cheeseman, C. R. Recycling and recovery routes for incinerated sewage sludge ash (issa): A review. Waste Management, 33(11), 2328 - 2340, 2013.

[2] Ingunza, M. P. D., Medeiros, S. A., and Santos Júnior, O. F. Sewage sludge as raw-material in asphalt mixtures. Advanced Materials Research, 664, 638-643, 2013.

[3] Ingunza, M. P. D., Duarte, A., and Nascimento, R. Use of sewage sludge as raw material in the manufacture of soft-mud bricks. Journal of Materials in Civil Engineering, 23(6), 852-856, 2011.

[4] Kosior-Kazberuk, M. Application of ssa as partial replacement of aggregate in concrete. Polish J. of Environ. Stud., 20 (2 (2011)), 365-370, 2011.

[5] Horiguchi, T., Fujita, R., and Shimura, K. Applicability of controlled low- strength materials with incinerated sewage sludge ash and crushed-stone powder. Journal of materials in civil engineering, 23(6), 767-771, 2011.

[6] Garcés, P., Pérez Carrión, M., García-Alcocel, E., Payá, J., Monzó, J., and Borrachero, M. Mechanical and physical properties of cement blended with sewage sludge ash. Waste management, 28(12), 2495-2502, 2008.

[7] Cyr, M., Coutand, M., and Clastres, P. Technological and environmental behavior of sewage sludge ash (ssa) in cementbased materials. Cement and Concrete Research, 37(8), 1278 1289,2007

[8] Cheeseman, C. and Virdi, G. Properties and microstructure of lightweight aggregate produced from sintered sewage sludge ash. Resources, Conservation and Recycling, 45(1), 18 - 30, 2005.

[9] Fontes, C., Barbosa, M., Toledo Filho, R., and Gonçalves, J. Potentiality of sewage sludge ash as mineral additive in cement mortar and high performance concrete." International RILEM Conference on the Use of Recycled Materials in Building and Structures, C. F. H. E. Vázquez and G. Janssen, eds., RILEM Publications SARL, 2004.

[10] Monzó, J., Payá, J., Borrachero, M., and Girbés, I. Reuse of sewage sludge ashes (ssa) in cement mixtures: the effect of \{SSA\} on the workability of cement mortars. Waste Management, 23(4), $373-381,2003$.

[11] ABNT. Brazilian Standard Test Methods. NBR NM 23. Portland cement and other powdered material - Determination of density. Rio de Janeiro, 2001.

[12] ABNT. Brazilian Standard Test Methods. NBR NM 52. Fine aggregate - Determination of the bulk specific gravity and apparent specific gravity. Rio de Janeiro, 2009a.

[13] ABNT. Brazilian Standard Test Methods. NBR NM 248. Aggregates - Sieve analysis of fine and coarse aggregates. Rio de Janeiro.

[14] ABNT . Brazilian Standard Test Methods. NBR 5736. Pozzolanic Portland cement - Specification. Rio de Janeiro, 2003

[15] ABNT . Brazilian Standard Test Methods. NBR NM 67. Concrete Slump test for determination of the consistency. Rio de Janeiro, 1998

[16] ABNT . Brazilian Standard Test Methods. NBR 5738. Concrete Procedure of molding and curing of concrete test specimens. Rio de Janeiro, 2008.

[17] ABNT . Brazilian Standard Test Methods. NBR 9778. Hardened mortar and concrete - Determination of absorption, voids and specific gravity. Rio de Janeiro, 2009b.

[18] ABNT. Brazilian Standard Test Methods. NBR 5739. Concrete Compression test of cylindric specimens - method of test. Rio de Janeiro, 2007. 